\title{
Meningkatkan Kepuasan Wisatawan Berkunjung Kembali Pada Destinasi Bintan Lagoon Resort
}

\author{
Muamar Khadafi ${ }^{1}$, Dina ${ }^{2}$ \\ ${ }^{1}$ Universitas Internasional Batam, muamar.khadafi@uib.ac.id \\ ${ }^{2}$ Universitas Internasional Batam, dina.khoo77@gmail.com
}

\begin{abstract}
ABSTRAK
Pariwisata merupakan industri memberikan dampak multiplier effect dan sangat mempengaruhi perputaran roda perkonomian sebagai penyumbang devisa bagi Negara. Indonesia memiliki wilayah teritorialnya berupa $70 \%$ lautan memiliki sumber daya alam, sebagai objek dan destinasi wisata yang menarik bagi wisatawan Nusatara terlebih wisatawan mancanegara. Salah satuya adalah bagian barat Indonesia yaitu Pulau Bintan kawasan tersebut terkenal dengan nama Bintan Lagoon Resort. Ketika hari libur panjang mengalami peningkatan wistawan, High season kunjungan wisatawan melebihi kapasitas dari akomodasi yang tersedia di Kawasan Bintan Lagoon Resort sehingga mengurangi kenyamanan wisatawan ketika berlibur. Hal tersebut akan mempengaruhi tingkat kepuasan wisatawan. Penelitian ini mengunakan metode penelitian kuantitatif untuk mengukur kepuasan pelayanan wisatawan di kawasan Bintan Lagoon Resort. Proses penelitian menggunakan data berupa angka sebagai alat untuk menemukan mengenai apa yang ingin diketahui. Varibel yang akan di teliti sejauh mana variabel (x) pelayanan dan kepuasan mengaparuhi terhadap niat wisatawan untuk berkunjung kembali, revisiter intentions dan variabel (y). Hasil penelitian kepuasan berkunjung kawasan Bintan Lagoi tergolong pada kategori baik hal ini dapat di lihat dari suatau produk dan jasa yang dapat meningkatkan rasa senang dan ingin kembali menggunakan produk atau jasa tersebut. Baik buruk kualitas pelayanan sangat berpengaruh terhadap kepuasan tamu. Oleh sebab itu pihak pengelola kawasan Bintan Lagoon Resort dan hotel harus mampu mempertahankan dan menyediakan semua kebutuhan, keinginan, serta harapan tamu, agar tamu merasa senang dan puas dalam kunjungannya, serta akan merekomendeasikan kepada koleganya.
\end{abstract}

Kata Kunci: Kepuasan, Pelayanan, Niat Wisatawan Berkunjung Kembali

\begin{abstract}
Tourism is an industry that generates multiplier effect and greatly affects the economy cycle as a foreign exchange contributor. Indonesia has $70 \%$ of sea territory with natural resources as tourist objects and destinations that attract tourists both domestic and foreign. One of tourist destinations in the west Indonesia is Bintan Island with its famous area Bintan Lagoon Resort. In long holiday, the number of tourists coming to this place is increasing. In high season, their visit is exceeding accommodation capacity in Bintan Lagoon Resort so that it reduces the comfort of vacation. This situation will influence the level of tourist satisfaction. This research used quantitative research method to measure tourist satisfaction on services in Bintan Lagoon Resort. The research process used numeric data as a tool to find out the answer of research question. The variables to be examined were to what extent variable $(x)$ services and satisfaction influenced tourists' re-visit intention and variable (y). The research result shows that visit satisfaction in Bintan Lagoi is in good category. This can be seen from products and services that increase happiness and willingness to re-consume the products and services. Good and bad quality of services greatly influences tourist satisfaction. Therefore, the management of Bintan Lagoon Resort and Hotel must be able to maintain and provide what tourists need, want and expect so that they are happy and satisfied in their visit and they will recommend this place to their colleagues as well.
\end{abstract}

Keywords: Satisfaction, Services, Tourists' Intention To Re-Visit

Naskah diterima: 8 Agustus 2020, direvisi: 19 Agustus 2020, diterbitkan: 27 Agustus 2020 


\section{PENDAHULUAN}

Pariwisata merupakan tulang punggung perekonomian di Indonesia, sebagai penyumbang devisa kedua setelah industri kelapa sawit. Saat ini Kementerian Pariwisata berorientasi pada pengembangan destinasi wisata, karena sektor pariwisata diharapkan dapat menjadi tulang punggung perekonomian dari sektor non migas (Hariyanto, 2017). Disisi lain pariwisata menyerap tenaga kerja dengan memberdayakan masyarakat setempat. Sejalan dengan program pemerintah, Kememterian Pariwisata berupaya secara maksimal mengembangkan potensi wisata dan meningkatkan pendapatan masyarakat terutama di objek dan destinasi Wisata (ODTW) (Sedarmayanti 2014). Sektor pariwisata nasional kini menjadi primadona baru bagi pembangunan nasional. Sumbangan devisa maupun penyerapan tenaga kerja dalam sektor ini memberikan kontribusi yang signifikan untuk devisa negara (Chandra and Damarjati 2017).

Indonesia merupakan negara kepulauan terbesar terdiri $70 \%$ dari lautan dan daratan $30 \%$. wilayah teritorialnya berupa lautan yang memiliki sumber daya alam, sebagai objek dan destinasi wisata (ODTW), yang menarik bagi wisatawan Nusatara (wisnus) maupun wisatawan mancanegara (wisman) (Diana Suheri 2015).

Bagian barat Indonesia terdapat Kepulauan Riau (KEPRI) memiliki sumber daya alam pesisir, dengan pulau-pulau kecil yang memiliki keindahan alam yang luar biasa. Hal tersebut sebagai daya tarik wisata berpotensi untuk dikembangkan menjadi pariwisata bahari di KEPRI (Gde Sugihamretha 2018). Salah satu destinasi wisata yang menjadi kebanggan Kepulauan Riau adalah Kabupaten Bintan, memiliki sumber daya alam yang masih asli. Keindahan bahari yang sangat indah sehingga menjadi daya tarik wisnu maupun wisman untuk berkunjung ke kawasan dan objek wisata yang berada di Pulau Bintan. Penelitian Achmad (2017), memberi gambaran perkembangan pembangunan di provinsi kepulauan yang memiliki potensi yang khas, bila dimanfaatkan dengan optimal dapat menghasilkan pertumbuhan ekonomi yang tinggi, mampu mensejahterakan rakyatnya. Pulau Bintan memiliki garis pantai pasir putih yang sangat indah terutama dibagian utara Pulau Bintan, kawasan tersebut adalah Bintan. Lagoon Resort, orang sering menyebutkan dengan nama Bintan Lagoi (Aditha Agun Prakoso 2019). Pada umumnya masyarakat local seringnmenyebutnya dengan nama kawasan Bintan Lagoi. Kawasan Bintan Lagoi dikenal dengan Wisata pantai lagoi memiliki keindahan alam yang mempesona dan memiliki berbagai macam fasilitas, serta akomodasi yang dibangun untuk memberikan fasilitas dan kenyamanan serta memanjakan para wisatawan. Wisatawan yang datang ke Kawasan Lagoi, tersedia berbagai jenis akomodasi dan fasilitas lainnya seperti; vila, hotel berbintang dilengkapi bar, resort, spa mewah, dan diskotik. Kolam renang yang besar berstandar internsional, lapangan golf, terminal ferry, (Aditha Agung Prakoso 2019).

Berdasarkan data Badan Pusat Statistik (BPS), pada tahun 2018 data kunjungan jumlah wisatawan meningkat di bulan Desember mencapai jumlah 61.258 jiwa. Bulan Desember merupakan akhir tahun, para pekerja dan anakanak sekolah libur serta menyambut hari Natal dan Tahun baru, merupakan high season. Disisi lain ketika High season kunjungan wisatawan melebihi kapasitas dari akomodasi yang tersedia di pulau Bintan, sehingga diduga ada kemungkinan mengurangi kenyamanan wisatawan dalam berlibur di kawasan Bintan lagoi. Penelitian dilakukan untuk mengetahui sejauh mana pengaruh kepuasan tamu terhadap keinginan untuk kembali mengunungi destinasi wisata Bintan Lagoi

\section{LITERATUR REVIEW}

\section{Wisatawan}

Wisatawan adalah setiap orang yang datang di suatu wilayah dengan alasan bukan untuk menetap atau berkerja di di suatu tempat atau wliyah tersebut (Suryadana, Octavia 2015). Ruang lingkup perjalanan Wisata, maka dapat di bagi beberapa jenis wistawan sebagai berikut.

a. Wisatawan asing

Orang asing yang melakukan perjalanan wisata datang dan memasuki Negara lain yang buka negaranya.

b. Domestic foreign tourist

Sesorang yang berdiam atau tinggal pada suatu Negara, dan melakukan perjalanan wisata di wilayah negera di mana wisatawan tersebut tinggal.

\section{c. Domestic tourist}

Wisatawan atau seseorang warga negara yang melakukan perjalanan wisata dalam batas wilayah negeranya sendiri.

d. Indigenous foreign tourist

Sesorang karena tugasnya atau jabatnnya di luar negeri, pulang ke negara asalnya dan melakukan perjalanan wisata di wilayah negarannya sendiri.

e. Transit tourist 
Wisatawan yang sedang melakukan perjalanan wisata ke suatu negara tertentu, dan menumpang kapal udara atau kapal laut ataupun kereta api. Dalam perjalanannya melintas atau singgah pada suatu pelabuhan/airport/stasion di luar wilayah atau negara yang ditujuh bukan atas kemaunnya sendiri.

\section{f. Business tourist}

Wisatawan yang melakukan perjalanan, orang asing atau warga negara sendiri untuk tujuan lain bukan Wisata. Kemudian setelah selesai urusan atau bisnisnya maka mengisi waktu luangnya untuk berwisata.

\section{Objek dan Destinasi}

Objek wisata adalah perwujudan dari ciptaan manusia, tata hidup, seni budaya, serta sejarah bangsa, dan tempat atau keadaan alam yang memiliki daya tarik untuk dikujungi wisatawan (Asriandi 2016). Objek wisata dibangun dan dikembangkan sehingga mempunyai daya tarik dan diusahakan sebagai tempat yang dikunjungi wisatawan. Obyek wisata dapat berupa wisata alam seperti gunung, danau, pantai, laut, atau berupa objek bangunan seperti museum, benteng, situs peninggalan sejarah.

Menurut (Kotler 2010) destinasi wisata adalah tempat dengan bentuk yang memiliki batasan nyata atau berdasarkan persepsi, baik berupa batasan secara fisik seperti pulau, secara politik, atau berdasarkan pasar. Destinasi wisata dapat dikelompokan berdasarkan ciri-ciri destinasi tersebut yaitu sebagai berikut:

a. Destinasi sumber daya alam, seperti iklim, pantai, hutan.

b. Destinasi sumber daya budaya, seperti tempat bersejarah, museum, teater dan masyarakat lokal.

c. Fasilitas rekreasi, seperti taman hiburan

d. Event, seperti pesta kesenian Bali, pesta danau Toba, pasar malam.

e. Destinsi wisata kuliner, belanja seperti bazzar.

f. Daya tarik psikologis, seperti pertualangan, perjalanan romantis, keterpencilan.

\section{Kepuasan Wisatawan dan Kunjungan Kembali}

Dalam dunia pariwisata pelayanan merupakan salah satu variabel penentu kepuasan wisatawan. Kepuasan pengunjung merupakan tingkat kepuasan sesorang setelah membandingkan kinerja produk yang dirasakan dengan harapannya. Dalam menilai tingkat kepuasan dilakukan pengukuran antara kesesuaian harapan wisatawan dilayani dibandingkan dengan pelayanan nyata yang diberikan pengelola (Priyanto 2016). Pernyataan lain semakin tinggi kepuasan sesorang wisatawan terhadap kualitas pelayanan wisata yang baik, maka kepuasan yang didapatkan akan semakin tinggi. demikian juga sebaliknya jika yang di rasakan lebih rendah dari didapatkan maka wisatawan tidak memiliki rasa puas pada destinasi tersebut.

\section{METODOLOGI PENELITIAN}

Menurut Darmawan (2013), penelitian kuantitatif adalah suatu proses penelitian yang menggunakan data berupa angka sebagai alat menemukan keterangan mengenai apa yang ingin ketahui. Teknik pengumpulan data yang digunakan dalam penelitian ini berupa observasi, kuesioner, wawancara terstruktur, pedoman observasi dan studi kepustakaan, untuk dokumentasi menggunakan camera digital. Teknik penelitian digunakan untuk mendapatkan data yang akurat tentang situasi dan kondisi pelayanan kepada wisatawan di kawasan Bintan Lagoi. Varibel yang akan di teliti sejauh mana variabel (x) pelayanan dan kepuasan mengaparuhi terhadap niat wisatawan untuk berkunjung kembali (revisit intentions) dan variabel (y).

Siregar (2013) uji reliabilitas adalah untuk mengetahui sejauh mana hasil pengukuran tetap konsisten, apabila dilakukan pengukuran dua kali atau lebih terhadap gejala yang sama dengan menggunakan alat pengukuran yang sama pula. Uji reliabilitas dapat dilakukan dengan cara tes ulang (retest), terhadap subjek yang sama, dilakukan dalam waktu yang berlainan. Hasil penelitian pertama dikorelasikan dengan hasil penelitian kedua untuk memperoleh koefisien korelasinya (r) yaitu koefisien reliabilitas test ulang dengan statistik korelasi (product moment) menggunakan SPSS versi 17.0. Pengujian reliabilitas dalam penelitian ini dilakukan dengan menggunakan koefisien Cronbach Alpha, yaitu koefisien keandalan yang menunjukan seberapa baiknya item butir dalam suatu kumpulan secara positif berkorelasi satu sama lain (Noor, 2014). Kehandalan (reliabilitas) tersebut ditentukan oleh kriteria jika koefisien Cronbach Alpha $>0,50$, maka hal ini menunjukkan kehandalan (reliabilitas) instrumen. Jika koefisien. Cronbach Alpha $<0,50$, maka hal ini menunjukkan kurang handalnya instrumen. 
HASIL DAN PEMBAHASAN

Akomodasi di Bintan Lagoon Resort (Bintan Lagoi )

Bintan merupakan kepulauan terbesar yang berada di provinsi Kepulauan Riau (KEPRI), pulau Bintan sangat berdekatan dengan Negara Singapur, oleh sebab itu wisatawan terbesar datang dari Negara Singapur. Kepulauan Bintan memiliki pantai yang spektakuler luasnya 23.000 hektar, dengan hamparan pasir putih. Destinasi utama di Kepulauan Bintan adalah wisata resort selain wisata bahari. Kawasan di Bintan Lagoi terletak di Bagian Utara Pulau Bintan, merupakan salah satu pusat kawasan yang dijadikan sebagai destinasi dan memiliki obyek wisata yang menarik.

Berdirinya obyek Wisata Bintan Lagoi adanya kerjasama bisnis yang dilakukan oleh Indonesia dengan Negara tetangga yaitu Singapura, kerja sama tersebut dilakukan karena Singapura tidak memiliki banyak sumber daya alam. Kerja sama untuk saling membantu dan bertukar pikiran dalam pembangunan objek wisata yang berkualitas dan mampu berdaya saing.

Sektor hotel dan restoran pada masa kini menjadi andalan kegiatan ekonomi di kawasan Bintan Lagoi sebagai salah satu tujuan wisata, baik wisata alam maupun yang buatan (man made). Hotel yang telah dibangun di kawasan Lagoi saat ini terdiri dari beragam fasilitas. Para investor masih membangun tempat peristirahatan baru demi memenuhi kebutuhan wisatawan yang datang dari luar kota maupu wisman. Akomodasi resort dan hotel di kawasan Bintan Lagoi saat ini sudah dibangun sekitar 1.755 kamar dengan berbagai kelas yang berbeda (Josep Oktaranda 2019). Berbagai macam tipe akomodasi mulai resort, villa, dan hotel. Resort banyak terdapat di kawasan Bintan Lagoi karena memiliki pemandangan laut dan hamparan pasir putih yang menjadi daya tarik utama bagi wistawan.

\section{Resort}

Bintan Lagoi memiliki akomodasi dinilai sangat baik, memiliki resort yang berbintang 5 (lima) dengan berbagai macam konsep dan berstandar internasional. Wisatawan yang berkunjung melakukan akses langsung untuk reservasi resort atau villa dekat dengan pantai. Berikut ini adalah Resort dan villa berbintang yang di berada di kawasan Bintan Lagoi.
Tabel 1. Resort berbintang di Bintan Lagoi

\begin{tabular}{|c|c|c|}
\hline No & Nama & Alamat \\
\hline 1 & $\begin{array}{l}\text { Banyan } \\
\text { Tree Bintan }\end{array}$ & $\begin{array}{l}\text { J1. Teluk Berembang } \\
\text { Laguna Bintan Lagoi } \\
\text { 29155 Bintan Resort, } \\
\text { Kecamatan Teluk } \\
\text { Sebong }\end{array}$ \\
\hline 2 & $\begin{array}{l}\text { Angsana } \\
\text { Resort \& } \\
\text { Spa }\end{array}$ & $\begin{array}{l}\text { Jl. Teluk Berembang } \\
\text { Laguna Bintan Lagoi } \\
29155 \text { Bintan Resort, } \\
\text { Kecamatan Teluk } \\
\text { Sebong }\end{array}$ \\
\hline 3 & $\begin{array}{l}\text { The } \\
\text { Sanchaya } \\
\text { Resort }\end{array}$ & $\begin{array}{l}\text { (Lagoi Bay } 21 \text { Villas, } \\
9 \text { Suites) Sebong } \\
\text { Lagoi, Kecamatan } \\
\text { Teluk Sebong }\end{array}$ \\
\hline 4 & $\begin{array}{l}\text { Bintan } \\
\text { Lagoon } \\
\text { Resort }\end{array}$ & $\begin{array}{lr}\text { Jl. Indera Segara Site } \\
\text { A12, Lagoi } & 29155 \\
\text { Bintan } & \text { Resort, } \\
\text { Kecamatan } & \text { Teluk } \\
\text { Sebong } & \\
\end{array}$ \\
\hline 5 & $\begin{array}{l}\text { Nirwana } \\
\text { Resort } \\
\text { Hotel }\end{array}$ & $\begin{array}{l}\text { Jl. Panglima Pantar, } \\
\text { Lagoi } 29155 \text { Bintan } \\
\text { Resort, Kecamatan } \\
\text { Teluk Sebong }\end{array}$ \\
\hline 6 & $\begin{array}{l}\text { Swiss-Bel } \\
\text { Hotel Lagoi } \\
\text { Bay }\end{array}$ & $\begin{array}{l}\text { J1. Raja Haji Site B4 } \\
\text { Lagoi Bay Rt03 Rw } \\
\text { 01, Kecamatan Teluk } \\
\text { Sebong }\end{array}$ \\
\hline 7 & $\begin{array}{l}\text { Club Med } \\
\text { Bintan } \\
\text { Island }\end{array}$ & $\begin{array}{l}\text { J1. Site A11, Lagoi } \\
\text { 29155 Bintan Resort, } \\
\text { Kecamatan Teluk } \\
\text { Sebong }\end{array}$ \\
\hline 8 & $\begin{array}{l}\text { Nirwana } \\
\text { Beach Club }\end{array}$ & $\begin{array}{lr}\text { Jl. Panglima } & \text { Pantar, } \\
\text { Lagoi } 29155 & \text { Bintan } \\
\text { Resort, Kec. Teluk } \\
\text { Sebong }\end{array}$ \\
\hline 9 & $\begin{array}{l}\text { Ria Golf } \\
\text { Lodge }\end{array}$ & $\begin{array}{lr}\text { Sebong } & \text { Lagoi, } \\
\text { Kecamatan } & \text { Teluk } \\
\text { Sebong } & \end{array}$ \\
\hline 10 & $\begin{array}{l}\text { The } \\
\text { Canopy }\end{array}$ & $\begin{array}{ll}\text { Sebong } & \text { Lagoi, } \\
\text { Kecamatan } & \text { Teluk } \\
\text { Sebong } & \end{array}$ \\
\hline
\end{tabular}

Sumber: Dinas Pariwisata Provinsi Kepri (2019)

\section{Vila}

Vila merupakan salah satu akomodasi yang di tawarkan di Bintan Lagoi yang berstandar internasional, pada setiap villa dan resort Bintan Lagoi memiliki fasilitas yang lengkap. Seperti terdapat kolam renang, mini bar, dapur, tempat pemangang barbeque, kamar, ruang tamu, ruang keluarga dan juga terdapat ruang makan. Berikut 
adalah villa yang terdapat di lagoi dengan fasilitas yang lengkap.

Tabel 2. Vila di Bintan Lagoi

\begin{tabular}{|c|c|c|}
\hline No & & Alamat \\
\hline 1 & $\begin{array}{l}\text { Indra Maya } \\
\text { Pool Villas }\end{array}$ & $\begin{array}{l}\text { Jl. Panglima } \\
\text { Lagoi } 29155 \text { Pantar, } \\
\text { Resort, Kecamatan } \\
\text { Teluk Sebong }\end{array}$ \\
\hline 2 & $\begin{array}{l}\text { Villa Aarya } \\
\text { Sebong } \\
\text { Lagoi }\end{array}$ & $\begin{array}{l}\text { Jl. Panglima } \\
\text { Lagoi } 29155 \text { Bantar, } \\
\text { Resort, Kecamatan } \\
\text { Teluk Sebong }\end{array}$ \\
\hline 3 & $\begin{array}{l}\text { Indramaya } \\
\text { Villa } \\
\text { Sebong } \\
\text { Lagoi }\end{array}$ & $\begin{array}{l}\text { Jl. Panglima Pantar, } \\
\text { Lagoi } 29155 \text { Bintan } \\
\text { Resort, Kecamatan } \\
\text { Teluk Sebong }\end{array}$ \\
\hline 4 & $\begin{array}{l}\text { Alila Villas } \\
\text { Resort }\end{array}$ & $\begin{array}{l}\text { Sebong } \\
\text { Kecamatan } \\
\text { Sebong }\end{array}$ \\
\hline
\end{tabular}

Sumber: Dinas Pariwisat Provinsi Kepri (2019)

\section{Kepuasan Tamu Berkunjung Kembali ke Bintan Resort}

Kualitas pelayanan terbaik adalahh menciptakan suatu kepuasan kepada tamuu atau secara spesifik kepada wisatawan. Kotler (2011), pelayanan adalah setiap tindakan atau perbuatan yang dapat di tawarkan oleh u pihak kepada pihak lain, yang bersifat intangible (tidak berwujud fisik) dan tidak menghasilkan kepemilikan sesautu. Parasuraman (1985) terdapat dua faktor utama yang mempengaruhi kualitas layanan, yaitu pelayanan yang diharapan (expected-service) dan pelayanan yang diterima oleh pengguna (perceived service). Apabila pelayanan yang diterima atau yang dirasakan (perceived service) sesuai dengan pelayanan yang diharapkan, maka kualitas layanan dipersepsikan baik dan memuaskan. Jika pelayanan yang diterima melampaui harapan tamu atau wisatawan, maka kualitas layanan dipersepsikan sebagai kualitas yang ideal. Sebaliknya jika kualitas layanan yang diterima lebih rendah dari pada pelayanan yang diharapkan, maka kualitas layanan dipersepsikan buruk. Kualitas pelayanan tergantung pada kemampuan penyelengara pelayanan dalam memenuhi harapan tamu secara konsisten.

Menurut Supranto, (2011) menjelaskan Kualitas pelayanan adalah sesuatu yang komplek terdiri dari lima unsur yaitu Fisik atau wujud (Tangibel), Kehandalan

(Reliabilitas),Tanggapan (Responsiveness), kepastian (Assurance) dan Empati (Empathy). Buruknya kualitas jasa yang diberikan penyedia jasa kepada tamu telah disadari, mengakibatkan kerugian yang dialami oleh pengusaha hotel. Wisatawan yang kecewa tidak hanya meninggalkan jasa layanan, tetapi juga akan menceritakan keburukan jasa yang diterima kepada orang lain. Berdasarkan definisi diatas kualitas pelayanan adalah tingkat unggulan dalam hal pelayanan yang diberikan kepada tamu. Meliputi : kualitas tersedia sarana dan fasilitas yang lengkap, serta clean, healty and safety atau bersih, sehat dan aman (CHS). Daryanto (2014) menyatakan kepuasan tamu adalah keadaan yang dicapai bila produk sesuai dengan kebutuhan atau harapan tamu dan bebas dari kekurangan. Kepuasan tamu juga dapat diidentifikasikan sebagai suatu keadaan semua kebutuhan, keinginan dan harapan tamu dapat terpenuhi melalui produk. Menurut Yamit Zulian (2013) Kepuasan pelanggan adalah hasil (outcome) yang dirasakan atas penggunaan produk dan jasa, sama atau melebihi harapan yang diinginkan. Kepuasan tamu tingkat perasaan seseorang setelah membandingkan kinerja/hasil yang di rasakan dengan harapannya (Supranto, 2011). Berdasarkan definisi kepuasan tamu merupakan persepsi pelanggan terhadap rasa puas pada suatau produk dan jasa yang dapat meningkatkan rasa senang dan ingin kembali menggunakan produk atau jasa tersebut. Seperti kepuasan dalam hal kenyamanan dan terpenuhinya kebutuhan dan keinginan wisatawan yang berkunjung Bintan Lagoi.

\section{KESIMPULAN DAN REKOMENDASI}

Berdasarkan hasil penelitian dan olahan data tersebut dapat di simpulkan sebagai berikut: Akomodasi di kawasan Bintan Lagoi tersedia dengan sangat baik dilengkapi sarana dan fasilitas yang berstandar internasional. Hal tersebut berdampak positif kepada wisatawan yang berkunjung dan menginap, pada umumnya adalah wisatawan dari mancanegara, terutama Singapur, Malaysia China dan Thailand.

Kepuasan pelanggan merupakan rasa puas pada suatau produk dan jasa yang dapat meningkatkan rasa senang dan ingin kembali menggunakan produk atau jasa tersebut. Secara keseluruhan penilaian yang diberikan tamu terhadap kepuasan berkunjung kawasan Bintan Lagoi tergolong pada kategori baik. Penelitian yang dilakukan, menunjukkan bahwa kualitas pelayanan mempengaruhi kepuasan pengunjung Bintan Resort Lagoon sebesar 50,9\%, sedangkan sisanya, yaitu $49,1 \%$ dipengaruhi oleh variabel- variabel 
lain yang tidak diteliti dalam penelitian ini. Berdasarkan hasil penelitian yang dilakukan terlihat dari pengkategorian skor dan nilai rata-rata pada statistik data hasil penelitian tentang kualitas pelayanan Bintan Lagoi dikategorikan baik, dengan persentase $52,1 \%$ berada pada rentang skor 4069. Dalam hal ini bisa di lihat kualitas pelayanan Bintan Lagoi masih harus ditingkatkan, terutama pada saat high season. Selanjutnya berdasarkan kategori skor dan nilai rata-rata pada statistik data hasil penelitian tentang kepuasan pengunjung di Bintan Lagoi dikategorikan baik, dengan persentase $73 \%$ berada pada rentang skor 2080. Jadi baik buruk kualitas pelayanan sangat berpengaruh terhadap kepuasan tamu, oleh karena itu pihak pengelola kawasan Bintan Lagoi resort dan hotel harus mampu meningkatkan kebutuhan, keinginan, dan harapan tamu agar tamu merasa senang dan puas dalam kunjungan nya dan akan kembali berkunjung untuk kesekian kalinya.

\section{REFERENSI}

Achmad, Suryana. 2017. Pembangunan Daerah Kepulauan : Studi Kasus Provinsi Kepulauan Riau Dan Provinsi Maluku Utara. Jakarta: Yayasan Pustaka Obor Indonesia.

Aditha Agung Prakoso, Yohana Aprilia de Lima. 2019. Strategi Pengembangan Pariwisata Kreatif Berbasis Masyarakat (Communitybased Creative Tourism) Di Bintan. Journal of Tourism and Creativity.

Asriandi, Ina. 2016. Strategi Pengembangan Obyek Wisata Air Terjun Bissapu Di Kabupaten Bantaeng. Makasar: Jurnal, Universitas Hasanuddin.

Chandra, Ardan Adhi, and Danu Damarjati. 2017. Tiga Tahun Jokowi-JK, Pariwisata Sumbang Devisa Terbesar Kedua. Detik Finance: 1-3.

Daryanto (2011). Sari Kuliah Manajemen Pemasaran. Bandung : PT.Sarana Tutorial Nurani Sejahtera.

Darmawan. (2013). Metode Penelitian Kuantitatif. Bandung: Remaja Rosdakarya.

Diana Suheri. 2015. Pengaruh Kualitas Pelayanan
Departemen Office Terhadap Kepuasan Tamu Di Banyan Tree Resort Bintan.

Gde Sugihamretha, I Dewa. 2018. "A Model of Development Maritime Tourism Competitiveness in Nikoi Island, Riau Islands Province. Jurnal Perencanaan Pembangunan: The Indonesian Journal of Development Planning 2(3): 320-32.

Hariyanto, Oda I .B. 2017. "The Meaning Of Offering Local Wisdom In Ritual Panjang Jimat." International Journal Of Scientific \& Technology ResearcH 6(06): 239-44.

Kotler, Philip. 2010. Manajemen Pemasaran. Edisi Tiga Belas Bahasa Indonesia. Jakarta: Erlangga.

Noor Juliansyah. 2011. Metodologi Penelitian. Jakarta.

Parasuraman, A., Zeihaml, V. A., \& Berry, L. L. (1985). A conceptual model of service quality and its implications for future research. Jurnal of Marketing, 49, 41-50.

Priyanto, R. 2016. Pengaruh Kualitas Pelayanan Terhadap Kepuasan Dan Loyalitas Pengunjung Saung Angklung Udjo. Jurnal Pariwisata.

Supranto. (2011). Pengukuran Tingkat Kepuasan Pelanggan. Jakarta : Rineka Cipta.

Siregar, S. (2013). Statistik Parametrik untuk Penelitian Kuantitatif. Jakarta. PT. Bumi Aksara

Sedarmayanti. 2014. Membangun Dan Mengembangkan Kebudayaan Dan Industri Pariwisata (Bunga Rambai Tulisan Pariwisata). Bandung: PT Refika Aditama.

Suryadana, Liga M \& Octavia. 2015. Pengantar Pemasaran Pariwisata. Bandung: Alfabeta

Yamit, Z. (2013). Manajemen Kualitas Produk \& Jasa, Cetakan ke-6, Yogjakarta

Yosep Oktaranda. 2019. Dampak Industri Pariwisata Lagoi Bertaraf Internasional Yang Dikelola Oleh PT. BRC Terhadap Pendapatan Asli Daerah Kabupaten Bintan Provensi Kepulauan Riau. 